\title{
Chemical constituents and bioactivity of Piper sarmentosum: a mini review
}

\author{
${ }^{1}$ Azelan, A., ${ }^{1, *}$ Taher, Z.M., ${ }^{3}$ Sasano, S., ${ }^{4}$ Ariga, T. and ${ }^{1}$ Aziz A.A \\ ${ }^{1}$ Institute of Bioproduct Development (IBD), Universiti Teknologi Malaysia (UTM), Johor Bahru, Malaysia. \\ ${ }^{2}$ Faculty of Chemical Engineering and Energy, Universiti Teknologi Malaysia (UTM), Kuala Lumpur, \\ Malaysia. \\ ${ }^{3}$ Faculty of Engineering (Chemical Engineering), Tokyo University of Agriculture and Technology Tokyo, \\ 184-8588, Japan \\ ${ }^{4}$ Faculty of Engineering (Applied Chemistry), Tokyo University of Agriculture and Technology Tokyo, 184- \\ 8588, Japan
}

\author{
Article history: \\ Received: 8 March 2020 \\ Received in revised form: 26 \\ August 2020 \\ Accepted: 26 August 2020 \\ Available Online: 2 \\ September 2020 \\ Keywords: \\ Piper sarmentosum, \\ Phytochemical, \\ Processing, \\ Biological activities
}

\begin{abstract}
Herbs with medicinal potential are important for health and wellness. The main aim of this review article was to disseminate important information regarding the use of Piper sarmentosum as natural medicine. P. sarmentosum have been reported to possess a varying degree of hypoglycemic, antidiabetic and other additional properties. The antioxidant properties of the herbs may be effective in controlling the oxidative damage. The review article highlights the positive role of traditional herbs as alternative medicine.
\end{abstract}

DOI:

https://doi.org/10.26656/fr.2017.4(S2).S10

\section{Introduction}

Herbal remedies played an enormously important role in the maintenance of human health throughout the history of mankind. Over $50 \%$ of modern clinical are sourced from various plants extracts and have been employed as supplements and nutraceuticals (Bradley, 1992; Sivasubramanian and Brindha, 2014). The genus Piper, widely distributed in the tropical and subtropical region of the world, is often used as food flavouring agents, traditional medicines (Burkill, 1966) and pest control agents (Nair and Burke, 1990, Hussain et al., 2012). P. sarmentosum Roxb. (Piperaceae), locally known as kadok, is a glabrous, creeping terrestrial herb about $20 \mathrm{~cm}$ tall. The leaves are dark green and variable in shape and size, usually, heart shape and cordate with 2 $-8 \mathrm{~cm}$ long petiole (Malaysian Herbal Monograph). Kadok is well known for its medicinal properties, such as its antibacterial, antiprotozoal, antioxidant, antimalarial and hypoglycaemic effects (Zaidan et al., 2005). The picture of the plant is shown in Figure 1.

In the Malay and Indonesian Archipelago, the leaves and roots of this plant are used for the treatment of toothache, fungoid dermatitis on the feet, coughing

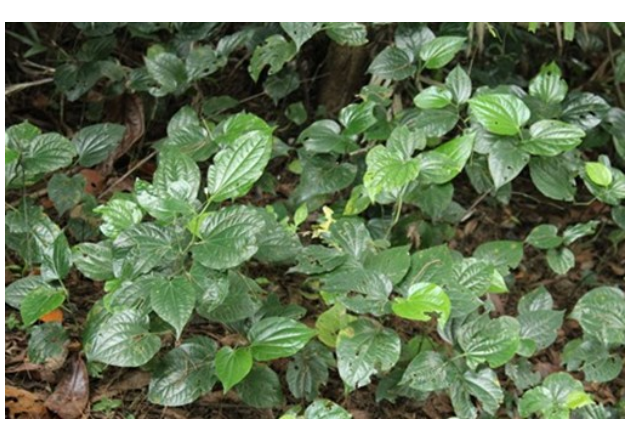

Figure 1. P. sarmentosum Roxb. (Malaysian Herbal Monograph)

asthma, and pleurisy (Perry, 1981). In Malaysia, $P$. sarmentosum leaves and roots are applied to the forehead to relieve headache while its decoction is utilized to cure muscle weakness and pain in the bones (Perry, 1981). In Indonesia, $P$. sarmentosum rootlets are chewed with betel nut and the juice is swallowed to treat coughs and asthma. It is also chewed with ginger to treat toothache or chewed with a little nutmeg and ginger to treat pleurisy (Perry, 1981). Warmed leaves coated with coconut oil are applied to the painful chest while the finely ground leaves mixed with a small amount of water are smeared on the throat to treat coughs. In Thailand, 
the roots are used as carminative and stomachic (Perry, 1981) while the fruits and leaves are used as an expectorant (Pongboonrod, 1976; Rukachaisirikul et al., 2004). This review describes the chemical constituents of $P$. sarmentosum and its bioactivity as the significant plant of interest. In South-East Asia, the plant has been discovered, however, extensive research to develop further still limited. In Panama, researchers have been working to explore the medicinal potential of this significant plant for its ethnomedical uses and pharmacological activities as this Piperaceae family occupying fifth place in Panamanian Flora (DurantArchibold et al., 2018). Due to great demand, scientific studies have been extensively carrying out worldwide. Most of the studies are focusing on biological activities of plant extracts, toxicology based on dosage and marker compound identification. It is believed that herbal product with known quality in terms of phytochemical profile and biological property will increase the value of the particular herbal product significantly. The information provided in this review will be of value not only for the discovery of pharmacological use in new drugs preparation but also to promote the use as the ingredients of traditional medicine.

\section{Material and methods}

The present review paper considered the literature published prior to 2020 on chemical constituent, pharmacological activities, biological activities and ethnomedicinal uses. This review considered peerreviewed research papers available at databases as Scopus, Science Direct or Google Scholar.

\section{Extraction methods}

The separation of compounds from natural products is becoming an important part for food, flavour, fragrance and pharmaceutical industries. Food industries have to deal with handling complex molecules such as chemical constituents or phytochemicals (Tiwari, 1995). Therefore, method of extraction that being employed is important to ensure the quality and quantity of the target compound. There are various methods to extract $P$. sarmentosum and one of them is using soxhlet apparatus (Thitima et al., 2004). Solvent extraction of solid samples, which is commonly known as solid-liquid extraction, but which should be referred to, in a more correct use of the physicochemical terminology, as leaching or lixiviation, is one of the oldest ways of solid sample pretreatment. The most outstanding advantages of conventional Soxhlet are as follows: the sample is repeatedly brought into contact with the fresh portions of the solvent, thereby helping to displace the transfer equilibrium (de Castro and García-Ayuso, 1998).
P. sarmentosum also can be extracted by using reflux (Hussain et al., 2008). Reflux is a technique involving the condensation of vapours and the return of this condensate to the system from which it originated (Proestos and Komaitis, 2008).

\section{Phytochemical constituents of P. sarmentosum}

$P$. sarmentosum is rich in bioactive compounds including amides, alkaloids, flavonoids, tannins, saponins, glycosides, terpenoids and phenolic compounds (Mgbeahuruike et al., 2017) P. sarmentosum is reported to contain the isolation of a number of amides and phenylpropanoids (Likhitwitayawuid et al., 1987; Masuda et al., 1991; Stohr et al., 1999). The chemical constituents of $P$. sarmentosum can be identified using Gas Chromatography-Mass Spectra (GC-MS) and the constituents were identified based on their retention times $\left(\mathrm{R}_{\mathrm{f}}\right)$ values. The molecular structures of the various compounds found in $P$. sarmentosum are shown in Table 1.

Rukachaisirikul et al. (2004) isolated eight amides (pellitorine, guineensine, brachystamide $\mathrm{B}$, sarmentine, brachyamide B, 1-piperettyl pyrrolidine, 3', 4',5'trimethoxycinnamoyl pyrrolidine and sarmentosine), two lignans $((+)$-asarinin and sesamin) and four other compounds (1-(3,4-methylenedioxyphenyl)-1Etetradecene, methyl piperate and, a mixture of betasitosterol and stigmasterol) from the hexane and methanol extracts of $P$. sarmentosum. New phenylpropanoyl amides (chaplupyrrolidone A, chaplupyrrolidone B and deacetylsarmentamide B) were discovered by Damsud et al. (2013) which using bioassay-guided fractions and then further purified by chromatography techniques. Rahman et al. (2014) reported the extracts of fruits and leaves of $P$. sarmentosum gave the best matches of 28 compounds in the leaf extract and 24 compounds in the fruit extracts. Interestingly, extensive research was done by Chanprapai and Chavasiri (2017) successfully displayed 63 constituents of $P$. sarmentosum which, accounting of $99.9 \%$ of the oil and myristicin was the major components. Other compounds were presents including trans-caryophylle, $\alpha$-copaene, germacrene-D, $\beta$-cubenene and bis-(2-ethylhexyyl) phthalate. Sakilan et al.,2019 reported the phytochemicals of $P$. sarmentosum in leaf using ethanolic etxracts and displayed aloocimene, benzene propanoic acid, trans-caryophylle, $\alpha$-copaene, germacrene-D, cis-methyl isoeugenol,naphthalene, deltacaddinene, 3-(4-methoxyphenyl) propionic acid.

\section{Biological activities}


Table 1. The molecular structures of the various compounds found in P. sarmentosum

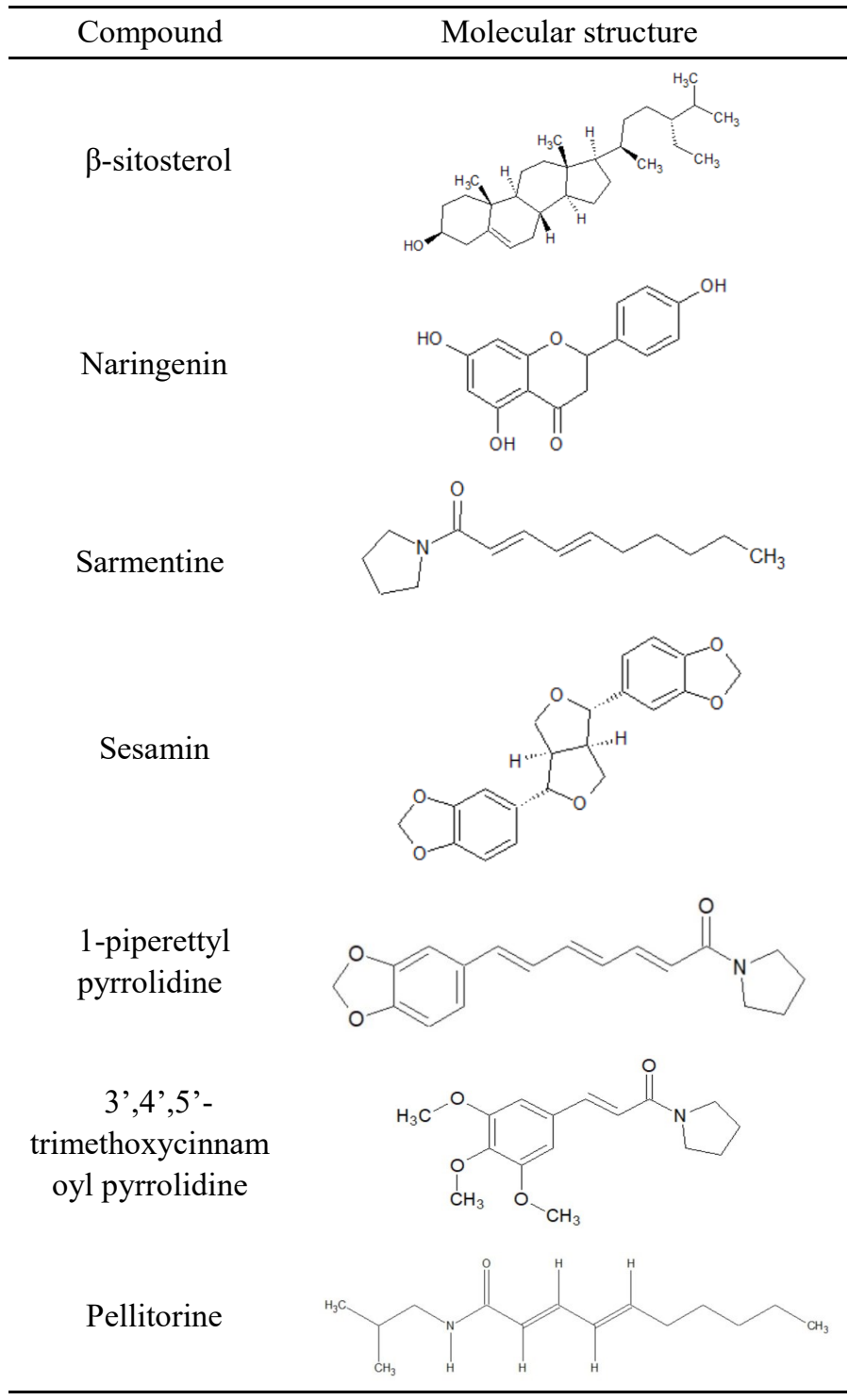

P. sarmentosum being a potential candidate as traditional medicine, the plant has been investigated for a number of activities like antiamoebic (Sawangjiaroen et al., 2004), antibacterial, antineoplastic (Toong and Wong (1989), neuromuscular blocking (Ridititid et al., 1998), hypoglycaemic (Peungvicha et al., 1998) and antimalarial (Najib et al., 1999). Leaf extracts are reported to have antioxidants properties due to flavonoids. Fruit of the plant has shown anti-TB activity and different bioactive amides have been isolated (Thitima et al., 2004).

\subsection{Antioxidants}

Superoxide anion $\left(\mathrm{O}^{-}\right)$is a toxic by-product formed by the univalent reduction of ground-state molecular oxygen (Cunningham et al., 1987). Superoxide anion and its reduction products $\mathrm{H} 2 \mathrm{O} 2$ and $\bullet \mathrm{OH}$ produce a variety of effects on tissue macromolecules and have been implicated as participants in a variety of disease states. Since superoxide anions are produced as toxic byproducts of regular biochemical and metabolic reactions in the human biological system, a daily intake of natural antioxidant superoxide scavenger could prevent oxidative damage. A study by Vimala et al. (2003) reported that methanolic leaf extracts of $P$. sarmentosum and possessed a natural antioxidant superoxide scavenger, Naringenin. Naringenin belongs to the flavonoid group, 4', 5, 7-Trihydroxyflavanone. The Naringenin compound showed high superoxide scavenging activity that is $75.7 \%$ (Vimala et al., 2003).

The research by Chanwitheesuk et al. (2005) towards 43 edible plants shows that the methanolic extract of the leaves $P$. sarmentosum contain a high level of antioxidant activity with the index of 13.0. Antioxidant activity was determined by measuring the coupled oxidation of carotene and linoleic acid, as described by Hammerschmidt and Pratt (1978). The results suggest that the antioxidant activities of these plants may be attributed to the chemical components present, especially vitamin $\mathrm{E}$ and xanthophylls.

\subsection{Antimicrobial}

Increasing awareness of hazards associated with the use of antibiotics and chemical agents has accelerated investigations into plants and their extracts as new sources of antimicrobial agents. The increasing prevalence of multidrug-resistant strains of microorganism and the recent appearance of strains with reduced susceptibility to antibiotics raises the spectre of untreatable microbial infections and adds urgency to the search for new infection-fighting strategies. The presence of the phytochemicals like flavonoids, tannins, and steroids indicates that $P$. sarmentosum is rich in phenol compounds. Zaidan et al. (2005) reported the antibacterial activities of methanol extracts of $P$. sarmentosum leaves against Staphylococcus aureus and Pseudomonas aeruginosa. The research done by Lee et al. (2014) showed the methanol extracts of $P$. sarmentosum Roxb give high antibacterial activities against Escherichia coli, Burkholderia sp. and Haemophilus parasuis in proportion to high amounts of total polyphenol and flavonoid. Chemical compounds such as myristicin and brachyamide B which isolated from the essential oil of $P$. sarmentosum exhibited strong antifungal activity against Rhizoctonia solani and Bipolaris oryzae. Additionally, Brachyamide B and piperonal also showed strong antibacterial activity against Xanthomonas oryzae (Xoo) and pv. oryzicola (Xoc) (Chanprapai and Chavasiri, 2017).

The study done by Taweechaisupapong et al. (2010) reported the antimicrobial effects of $P$. sarmentosum extracts on Aggregatibacter actinomycetemcomitans, an oral microbe, which was tested by the disc diffusion method showed no inhibitory zone. The methanolic fruit 
extract of $P$. sarmentosum was found to be effective as antibacterial agents against the causal agent of sheath brown rot, Pseudomonas fuscovaginae (Rahman et al., 2016). The antibacterial activity of the fruit extract against the pathogenic bacteria $P$. fuscovaginae was measured by the diameter of inhibition zones produced and the MIC and MBC values. The results obtained from this study suggest that the fruit extract of $P$. sarmentosum has a potential to be developed as a novel bactericide.

\subsection{Antidepressant}

Different type of extracts of $P$. sarmentosum have been investigated for antidepressant-like effect in mice and few parameters were evaluated in the open field test (OFT), force swim test (FST) and tail suspension test (TST). The results indicate that $P$. sarmentosum increased the expression of brain-derived neurotropic factor (BDNF) and effective as an anti-depressant (Qing et al., 2017).

\section{Acknowledgements}

The authors would like to thank the Institute of Bioproduct and Development (IBD), Universiti Teknologi Malaysia for providing the necessary support for the study. This research was supported by NKEA Research Grant Scheme (NRGS) Vot. No 4H029 Universiti Teknologi Malaysia (UTM).

\section{References}

Bradley, P.R. (1992). British Herbal Compendium. Vol. 1, p. 112-114. Bournemouth, Dorset, UK: British Herbal Medicine Association.

Burkill, I.H., (1966). A Dictionary of the Economic Products of the Malay Peninsular, $2^{\text {nd }}$ ed., p. 1767 1784. Kuala Lumpur, Malaysia: Ministry of Agriculture and Cooperatives.

Chanprapai, P. and Chavasiri, W. (2017). Antimicrobial activity from $P$. sarmentosum Roxb. against rice pathogenic bacteria and fungi. Journal of Integrative Agriculture, 16(11), 2513-2524. https:// doi.org/10.1016/S2095-3119(17)61693-9

Chanwitheesuk, A., Teerawutgulrag, A. and Rakariyatham, N. (2005). Screening of antioxidant activity and antioxidant compounds of some edible plants of Thailand. Food Chemistry, 92(3), 491-497. https://doi.org/10.1016/j.foodchem.2004.07.035

Cunningham, M.L., Peak, J.G. and Peak, J.P. (1987). Single-strand DNA breaks in rodent and human cells produced by superoxide anion or its reduction products. Mutation Res 184(3), 217-222. https:// doi.org/10.1016/0167-8817(87)90019-8 de Castro, L.M.D. and García-Ayuso, L.E. (1998). Soxhlet extraction of solid materials: An outdated technique with a promising innovative future. Analytica Chemica Acta, 369(1-2), 1-10. https:// doi.org/10.1016/S0003-2670(98)00233-5

Hussain, K., Hashmi K.F., Latif, A., Ismail Z. and Sadikun, A. (2012). A review of the literature and latest advances in research of $P$. sarmentosum. Pharmaceutical Biology, 50(8), 1045-1052. https:// doi.org/10.3109/13880209.2011.654229

Hussain, K., Ismail, Z., Sadikun, A. and Ibrahim, P. (2008). Analysis of proteins, polysaccharides, glycosaponins contents of $P$. sarmentosum Roxb. and anti-TB evaluation for bio-enhancing/interaction effects of leaf extracts with Isoniazid (INH). Natural Product Radiance, 7(5),402-408

Lee, J.H., Cho, S., Paik, H.D., Choi, C.W., Nam, K.T., Hwang, S.G. and Kim, S.K. (2014). Investigation on Antibacterial and Antioxidant Activities, Phenolic and Flavonoid Contents of Some Thai Edible Plants as an Alternative for Antibiotics. Asian-Australas Journal of Animal Sciences, 27(10), 1461-1468. https://doi.org/10.5713/ajas.2013.13629

Likhitwitayawuid, K., Ruangrungsi, N., Lange, G.L. and Decicco, C.P. (1987). Structural elucidation and synthesis of new components isolated from $P$. sarmentosum (Piperaceae). Tetrahedron, 43(16), 3689-3694. https://doi.org/10.1016/S0040-4020(01) 86856-3

Masuda T., Inazumi, A., Yamada, Y., Padolina, W.G., Kikuzaki, H. and Nakatani, N. (1991). Antimicrobial phenylpropanoids from $P$. sarmentosum. Phytochemistry, 30(10), 3227-3228. https:// doi.org/10.1016/0031-9422(91)83180-S

Mgbeahuruike E.E, Yrjonen T., Vuorela H. and Holm Y. (2017). Bioactive compounds from medicinal plants: Focus on Piper species. South African Journal of Botany, 112, 54-69. https://doi.org/10.1016/ j.sajb.2017.05.007

Nair, M.G. and Burke, B.A. (1990). Antimicrobial Piper metabolite and related compounds. Journal of Agriculture and Food Chemistry, 38, 1093-1096. https://doi.org/10.1021/jf00094a041

Najib, N.A., Rehman, N., Furuta, T., Kojima, S., Takane, K. and Ali, M.M., (1999). Anti-Malarial activity of extracts of Malaysian medicinal plants. Journal Ethnopharmacol, $\quad 64(3), \quad 249-254 . \quad$ https:// doi.org/10.1016/S0378-8741(98)00135-4

Perry L.M. (1981). Medicinal Plants of East and Southeast Asia, p. 314-415. Cambridge, UK: MIT Press.

Peungvicha, P, Thirawarapan, S.S, Temsiririkkul, R., 
Wanabe, H., Prasain, J.K. and Kadota, S. (1998). Hypoglycemic effect of water extract of $P$. sarmentosum leaves in rates, Journal Ethnopharmacology, 60(1), 27-32. https:// doi.org/10.1016/S0378-8741(97)00127-X

Pongboonrod S. (1976). The Medicinal Plants in Thailand, p. 180. Bangkok: Kasembanakit Press.

Proestos, C. and Komaitis, M. (2008). Application of microwave-assisted extraction to the fast extraction of plant phenolic compounds. LWT - Food Science and Technology, 41(4), 652-659. https:// doi.org/10.1016/j.lwt.2007.04.013

Qing, L., Qu, F.L., Jiang, Y.-P., Rahman, K., Lee, K.-H., Han, T. and Qin, L.-P. (2017). P. sarmentosum Roxb. produces antidepressant-like effects in rodents, associated with activation of the CREB_BDNF_ERK signaling pathway and reversal of HPA axis hyperactivity. Journal of Ethnopharmacology, 199, 9-19. https:// doi.org/10.1016/j.jep.2017.01.037

Rahman, S.F.S.A, Sijam, K. and Omar, D. (2016). Antibacterial activity of the crude extract of $P$. sarmentosum against Pseudomonas fuscovaginae. International Journal of Applied Biology and Pharmaceutical Technology, 7(1), 67-72.

Rahman, S.F.S.A, Sijam, K., and Omar, D. (2014). Chemical composition of $P$. sarmentosum extracts and antibacterial activity against the plant pathogenic bacteria Pseudomonas fuscovaginae and Xanthomonas oryzae pv. Oryzae. Jounal Plant Disease Protection, 121, 237-242. https:// doi.org/10.1007/BF03356518

Ridititid, W., Rattanaprom, W., Thaina, P., Chittrakaran, S. and Sunbhanich, M. (1998). Neuromuscular blocking activity of methanolic extract of $P$. sarmentosum leaves in the rat phrenic neve hemi diaphragm preparation, Journal Ethnopharmacology, 61(2), 135-142. https://doi.org/10.1016/S0378-8741 (98)00025-7

Rukachaisirikul, T., Siriwattanakit, P., Sukcharoenphol K., Wongvein, C., Ruttanaweang, P., Wongwattanavuch, P. and Suksamrarn, A. (2004). Chemical constituents and bioactivity of $P$. sarmentosum. Journal of Ethnopharmacology, 93(23), 173-176. https://doi.org/10.1016/ j.jep.2004.01.022

Sakilan, J.M., Demayo, C.G. and Opanasopit, P. (2019). Phytochemical analysis and determination of antimicrobial, antioxidant and anticancer activity of the leaf ethanolic extracts of $P$. sarmentosum Roxb. in Lapuyan Zamboanga Del Sur, Philippines. International Journal Pharmaceutical Sciences and Research, 10(12), 5715-5722.
Sawangiiaroen, N., Sawangjiaroen, K. and Poonpanang, P. (2004), P. sarmentosum root and Quercus infectoria nut gall on caecal ameobiasis in mice. Journal Ethnoparmacology, 91(2-3), 357-360. https://doi.org/10.1016/j.jep.2004.01.014

Sivasubramanian, R. and Brindha, P. (2014). Centratherum Punctatum Cass-A Herbal Dietary Supplement in The Management of Cancer. International Journal of Pharmacy and Pharmaceutical Sciences, 6(Suppl. 1), 64-65.

Stohr, J.R., Xiao, P.G. and Bauer, R. (1999). Isobutylamides and a new methylbutylamide from $P$. sarmentosum. Planta Medica, 65(2), 175-177. https://doi.org/10.1055/s-2006-960460

Subramaniam, V., Adenan, M.I., Ahmad, A.R. and Sahdan, R. (2003). Natural Antioxidants: $P$. sarmentosum (Kadok) and Morinda elliptica (Mengkudu). Malaysia Journal of Nutrition, 9(1), 41 $-51$

Taweechaisupapong, S., Singhara, S., Lertsatitthanakorn, P. and Khunkitti, W. (2010). Antimicrobial effects of Boesenbergia pandurata and $P$. sarmentosum leaf extracts on planktonic cells and biofilm of oral pathogens. Pakistan Journal of Pharmaceutical Sciences, 23(2), 224-231.

Thitima, R., Puttan, S., Kanchanawadee, S., Chanika, W., Phongpan, R., Phaopong, W. and Apicart, S., (2004). Chemical constituents and bioactivity of $P$. sarmentosum, Journal Ethnopharmacology, 93(2-3), 173-176.

Tiwari, K.K. (1995) Extraction Technologies Related to Food Processing. In Gaonkar, A.G. (Ed). Food Processing: Recent Developments, p. 269-301. Amsterdam: Elsevier Science. https:// doi.org/10.1016/B978-044481500-2/50016-5

Toong, V.Y. and Wong, B.I. (1989), Phytochemistry of Medicinal Plants, P. sarmentosum. Proceedings: Traditional Medicine, Kuala Lumpur, 1998. Kuala Lumpur, University of Malaya: Institute of Advance Studies.

Zaidan, M., Noor Rain, A., Badrul, A., Adlin, A., Norazah, A. and Zakiah, I. (2005). In vitro screening of five local medicinal plants for antibacterial activity using disc diffusion method. Tropical Biomedicine, 22(2), 165-170. 